\title{
Un artista olvidado
}

\author{
A forgotten artist
}

José Roberto Saravia

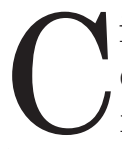
ierto día en que el reloj había decidido traicionarme y giró sus manecillas más rápidamente de lo que yo podía completar mis menesteres para salir de mi casa rumbo a la oficina, ocurrió un suceso inesperado. Dicho acontecimiento - trivial tal vez-sacudió con el sabor de la nostalgia la modorra de mi rutina. Recuerdo haberme visto forzado a abordar un taxi ese día. Se trataba de una medida desesperada; deseaba abrir un atajo hacia mi oficina antes de que la veloz e implacable hora de entrada me precediera y coronara su silenciosa victoria. En realidad, pensaba que mi día se convertiría a partir de ese momento en una sucesión de eventos amargos: el conductor a cuyo lado me había sentado - con su ceño fruncido, su bigote mal cuidado y su boca herméticamente cerrada- no aparentaba ser una persona del todo agradable.

"Bien, jaquí vamos hacia un día terrible!", me pronostiqué resignado mientras el sabor ácido de la prisa subía por mi paladar y me impedía apreciar el océano azul del cielo con la espuma de sus nubes sobre mí. El sol, cual gigantesca y brillante boya, flotaba en él sin preocupación alguna.

Miré de nuevo al conductor del taxi. ¿Qué ideas cruzarían por su mente como peatones en su camino mientras conducía en el más absoluto e incómodo mutismo? Percibí que me miró de reojo. Me figuré que él se preguntaba lo mismo sobre mí y pensé que el enano invisible de la tensión, aferrado implacablemente a mi espalda, le ofrecía un espectáculo sumamente divertido. Sin embargo, el hombre sin voz nada dijo. ¡Qué sorpresa!

Miré mi reloj. Se trataba de un modelo plástico a prueba de golpes y altamente resistente al agua; de hecho, soportaba sumergirse hasta 250 metros bajo el agua. Siempre me había sentido orgulloso de portar mi costoso reloj. Pensaba que indicaba status, pero su forma tosca y su color negro lo hacían ahora más semejante a un grillete que al aparato para medir el tiempo del cual me enorgullecía. Incluso, sus 250 metros de resistencia al agua me parecían estúpidos: iyo ni siquiera sabía 
nadar! Si me sumergía tan sólo cinco metros en el agua, jel maldito reloj sobreviviría pero yo no! Aparté mi vista de él como si me hubiese quemado los ojos.

Noté que el taxi disminuía su velocidad. El enano invisible asido a mi espalda clavó en mis hombros sus uñas encorvadas y sentí la puntada de dolor cavar hasta mi estómago. Miré a mi izquierda para saber la razón de la marcha más lenta. Instintivamente, abrí mi boca para dejar salir por ella un torrente de hiel que de seguro amargaría más mi día que el del hombre a mi lado. Sin embargo, no fui capaz de decir palabra alguna porque mis ojos no se encontraron con los del conductor.

El taxista también tenía vuelta su cabeza hacia su izquierda. En la acera, dos hombres retocaban un modelo a escala de una iglesia. La maqueta me parecía conocida y el nivel de detalles en ella me sorprendió... hasta olvidé mi prisa y me sentí aliviado.

En dos segundos dejamos atrás la escena. El conductor volvió a acelerar. Del colorido mundo en miniatura con iglesias a escala regresé a mi mundo gigante de rutinas grises y sin sentido. No obstante, la tensión en mí había desaparecido milagrosamente. ¿Habían rezado por mí los minúsculos ángeles que cuidaban aquella iglesia diminuta?

“:Sabe usted cuál era esa iglesia?”, me preguntó el hombre tosco detrás del volante. "¡Vaya! ¡Habla español después de todo!", me dije en una fracción de segundo.

“¿No es la Basílica de los Ángeles?”, respondí dudoso. En realidad no tenía idea de cuál iglesia podía ser, aunque estaba seguro de haberla visto antes.

El hombre me miró incrédulo. Por su mirada, cualquiera aseguraría que se hallaba observando un ejemplo de fauna extraterrestre...

"En realidad, era la Catedral de Notre Dame", dijo luego de un lapso incómodo para mí. Mi ignorancia me miró directamente a los ojos con un guiño burlón.

"iAh, claro! No la pude ver bien porque apenas la vi de reojo", mentí. Estaba seguro de que el conductor podía ver mi mentira pintada en mis ojos y mis mejillas, pero por suerte si él lo hizo, fue bastante condescendiente conmigo y no dijo nada.

"Yo lo sé por mi difunto padre", explicó mi interlocutor, siempre con sus ojos puestos en la carretera. Un auto pasó zumbando junto a nosotros. Probablemente su conductor - cuyo rostro no pude apreciar bien debido a la máscara de impaciencia que ostentaba- era ahora presa del enano maligno que antes mortificaba mis hombros con su peso.

"Mi padre, Fermín Pérez, quien murió hace ya veinticinco años, hacía de esos trabajos", continuó el taxista. Su voz adquirió más volumen y resonancia de repente.

"Él no tenía estudios, con costo salió de la escuela. Era un hombre sencillo pero hacía cualquier edificio de donde fuera con cartón. Solamente necesitaba una regla y pegamento. Su taller era una mesa vieja hecha con reglas de madera. Ahí era donde hacía todo", me explicó.

"Mi difunto padre...", continuó el hombre, ahora con su voz teñida de dorado por el orgullo, “... no había podido estudiar, pero era todo un artista. De todo el país, lo llegaban a buscar para encargarle trabajos. Él solamente pedía una fotografía del edificio en cuestión, y luego la analizaba un momento".

El taxista se detuvo. Me pareció que extraía viejos recuerdos de su 
mente como si se tratara de tesoros encerrados en algún cofre antiquísimo. Por fin prosiguió:

"Mi padre les decía entonces que volvieran en un mes, o dos, o lo que calculaba que le iba a tomar completar el trabajo. Los que le encargaban el trabajo regresaban en ese mismo plazo y de seguro, ya estaba listo el edificio en miniatura. ¡A veces hasta tardaba menos!”.

El taxi se detuvo en un semáforo. Varias personas cruzaron la calle ensimismadas en sus propios mundos. Todos entrarían tarde o temprano en alguno de los grandes edificios que se erguían altaneros, como desafiándose mutuamente para ver cuál alcanzaba antes el cielo.

"Un 26 de mayo, mi padre falleció", musitó el conductor aferrado al volante. "Con él, se perdió su arte, porque ninguno de nosotros pudo aprenderlo. No fue que no quisiéramos; era que no podíamos. No teníamos esa chispa que él tuvo. Mis cinco hermanos y yo tratamos de seguir sus pasos, pero de verdad no podíamos. Fue una lástima; el arte que tanto admirábamos se perdió porque ninguno de nosotros pudo aprenderlo. Al final, cada quien siguió su camino", concluyó mi interlocutor con voz nostálgica y distante.
Llegamos a mi destino. Pagué al hombre y salí del vehículo, aunque su historia no había salido de mi cabeza. Aparentemente, se quedaría allí para siempre.

El taxi se marchó. Antes de entrar en el edificio donde se hallaba mi oficina, miré hacia atrás. En la lejanía, se divisaba una iglesia modesta. "¿La habrá recreado en miniatura ese artista olvidado?", me pregunté.

Extendí mi mano con la palma vuelta hacia arriba. La iglesia, distante y silenciosa, cabía en ella. Miré al cielo sobre la edificación. Me sorprendí. Juraría que vi la figura transparente de un hombre gigantesco entre un par de nubes sobre la iglesia que yo, de modo metafísico, sostenía en mi mano. Tal vez fue mi imaginación, o a lo mejor fue un residuo de mi tensión anterior, no lo sé. Lo cierto es que se me ocurrió que podía ser el viejo artesano cuyo arte empírico alimentó a su familia. Seguramente, había terminado de construir esa iglesia que yo ahora sostenía y se marchaba a realizar su siguiente encargo.

"No... no es un artista olvidado", me corregí. "Hasta un perfecto extraño como yo lo admira ahora", sentencié mientras entraba por la boca de la mole gris de concreto hacia mi faena diaria. 
